\title{
Mycobacterium tuberculosis: escape room world champion
}

\author{
Thuc Anh Nguyen ${ }^{1}$, Sophie Croon ${ }^{1}$ and Ger Rijkers ${ }^{1,2^{*}}$ (D)
}

An escape room is a physical adventure game in which the players have to solve problems and develop a strategy to leave their confined physical space. In March 2017, Budapest hosted the first escape room championships, in which 22 countries participated; Slovenia won. If this championship would have taken place in the microbiological world, the winner probably would have been Mycobacterium tuberculosis (M. tuberculosis).

$M$. tuberculosis is the causative micro-organism of the most widespread infectious disease tuberculosis (TB). $M$. tuberculosis can be transmitted via air droplets into the lungs, where it is phagocytosed by alveolar macrophages. Normally, a macrophage would be able kill and digest the pathogen by fusing the phagocysome with a lysosome. However, in the case of M. tuberculosis, the bacterium can escape this lysosomal fusion which allows the bacterium to replicate and grow intracellularly in the phagocyte [1]. Because lysosomes contain a large arsenal of bactericidal enzymes, the prevention or postponement of fusion with the phagosome thus increases the chance of survival of the bacterium. Ironically, this type of host defense mechanism, phagocytosis, is beneficial to $M$. tuberculosis and other intracellularly growing bacteria such as Mycobacteria, Legionella and Salmonella species and Listeria monocytogenes; because by staying within the phagocytic cell, the microorganism is shielded from important components of the immune system including complement and antibodies. They extract the essential nutrients and minerals (including iron) directly from the host cell for their own growth, but in order to survive the intracellular microorganisms has to use 'stealth' techniques to escape bactericidal mechanisms of phagocytic cells.

As indicated above, $M$. tuberculosis can be taken up in lysosomes but after two to four days it can break out of the phagolysosome escaping its digestion and evades

\footnotetext{
* Correspondence: g.rijkers@ucr.nl

Editorial in Pneumonia on the occasion of World Tuberculosis Day 2019 (March 24)

${ }^{1}$ Department of Sciences, University College Roosevelt, P.O. Box 94, 4330 Middelburg, AB, Netherlands

${ }^{2}$ Laboratory for Medical Microbiology and Immunology, St Elisabeth Hospital, Tilburg, Netherlands
}

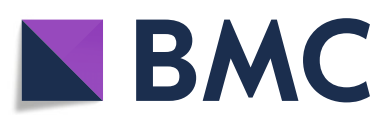

(c) The Author(s). 2019 Open Access This article is distributed under the terms of the Creative Commons Attribution 4.0 International License (http://creativecommons.org/licenses/by/4.0/), which permits unrestricted use, distribution, and

reproduction in any medium, provided you give appropriate credit to the original author(s) and the source, provide a link to the Creative Commons license, and indicate if changes were made. The Creative Commons Public Domain Dedication waiver (http://creativecommons.org/publicdomain/zero/1.0/) applies to the data made available in this article, unless otherwise stated.

into the cytoplasm (Fig. 1) [2, 3]. Moreover, the characteristic of $M$. tuberculosis as an escape artist can be further shown by its ability to disseminate from the primary site of infection to peripheral lymph nodes and blood stream [4]. It thus now becomes apparent that the multiple levels of escape mechanisms from the host immune system makes $M$. tuberculosis an extremely pathogenic bacteria.

The current treatment of TB consist of a series of antibiotics which have to be taken for 6 months [5]. A full course of therapy (completion of treatment) is however determined more accurately by the total number of doses taken, not solely by the duration of therapy. For example, the "6-month" daily regimen (given 7 days/ week) should consist of at least 182 doses of Isoniazid and Rifampin, and 56 doses of Pyrazinamide [6]. Antibiotic therapy hasn't changed much because only one TB drug has entered the clinical practice in the past 40 years. Also in terms of prevention of TB progress is slow. The BCG vaccine has been in use for almost a hundred years, but unfortunately only has a limited effect in preventing tuberculosis [7]. Thus TB remains one of the deadliest infections known to man, causing 10.0 million infections and 1.6 million deaths in 2017 [8]. Combining these figures with the increased rate of infections by multidrug resistant strains, which already account for $50 \%$ of infections in some countries [9], means that a more effective vaccine is urgently needed. BCG has shown to protect vaccinees against deadly disseminated forms of TB including life threatening TB meningitis. However, at a later stage of infection when $M$. tuberculosis, BCG becomes ineffective [10]. While BCG mainly induces a cellular immune response, recent research now also focuses on development of vaccines inducing a humoral response, with antibodies against $\alpha$-glucan, arabinomannan and lapidated arabinomannan [11]. There is a clear need for standardization of experimental designs with aligning of end-points which should facilitate the development of new vaccines [12]. Vaccine candidates, such as the ones mentioned above, could be combined in recombinant viral vectors [13]. In the 

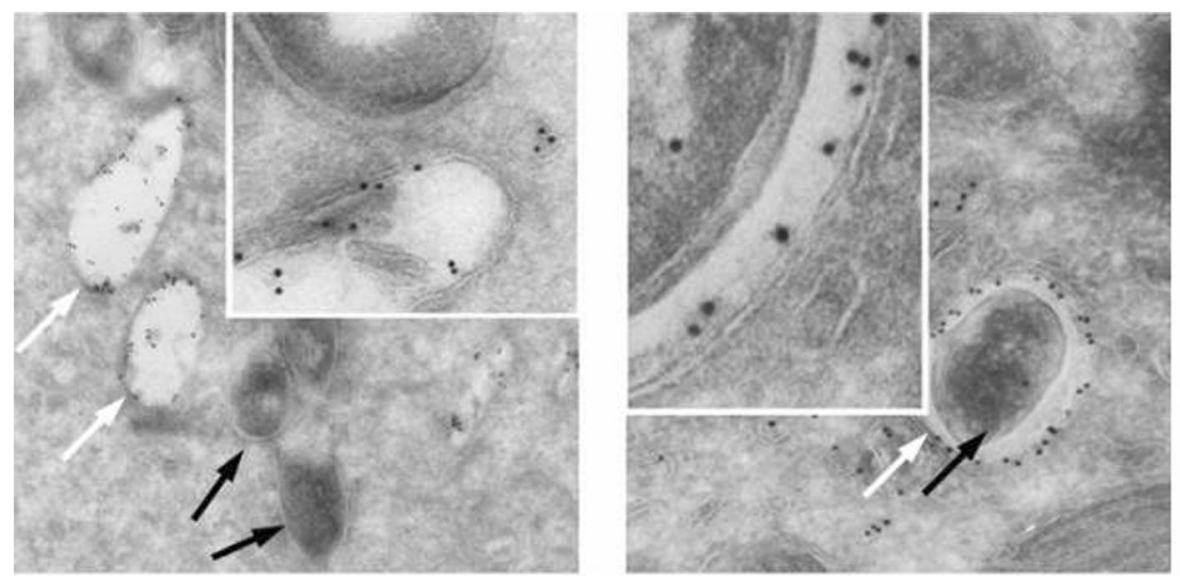

\section{Mycobacterium tuberculosis Mycobacterium bovis (BCG)}

Fig. 1 Mycobacterium tuberculosis breaks out of lysosomes. The left electron microscopic image shows M. tuberculosis bacteria (black arrows) in the cytoplasm of an infected dendritic cell. The remaining empty phagolysosomes (white arrows) have been stained with gold labeled antibodies against LAMP1 (lysosome associated membrane protein), a protein specifically for lysosomes Colloidal gold particles (visible as black dots) show the location of antibody binding (see also the inset on the photo). In the right figure a dendritic cell is infected with another mycobacterium strain, M. bovis. This is the mycobacterium from the BCG vaccine (Bacille Calmette Guérin) against tuberculosis. This mycobacterium remains within the lysosome. (Further details in reference [2])

development of better Mycobacterial vaccines it should also be kept in mind that a supraoptimal immune response may lead to considerable immunopathology $[14,15]$.

Although M. tuberculosis may be successful at escaping the phagolysosome, it is important that it does not escape our attention. Millions of patients are affected each year, and fully effective vaccines have not yet been developed. In order for this disease to stay on the radar, there is an annual World Tuberculosis Day on March 24. During this day, special attention is given to the victims of this infection, and to promote research leading to a better future for those that are currently infected, and those that will be infected in the future. Together, these efforts hopefully succeed in eradication of this disease, so that in the future it will fail to escape our attention once and for all.

\section{Acknowledgements}

Figure 1 courtesy of Professor Peter Peters, Institute of Nanoscopy, Maastricht University, The Netherlands.

\section{Funding}

No external funding was used for this work.

\section{Authors' contributions}

GTR conceived the idea for this editorial. TAN, SC, and GTR together wrote the manuscript. All authors read and approved the final manuscript.

\section{Competing interests}

The authors declare that they have no competing interests.

\section{Publisher's Note}

Springer Nature remains neutral with regard to jurisdictional claims in published maps and institutional affiliations.
Received: 22 February 2019 Accepted: 8 March 2019

Published online: 24 March 2019

\section{References}

1. Rohde K, Yates RM, Purdy GE, Russell DG. Mycobacterium tuberculosis and the environment within the phagosome. Immunol Rev. 2007;219(1):37-54.

2. van der Wel N, Hava D, Houben D, Fluitsma D, van Zon M, Pierson J, Brenner M, Peters PJ. M. Tuberculosis and M. Leprae translocate from the phagolysosome to the cytosol in myeloid cells. Cell. 2007;129(7):1287-98.

3. Delogu G, Provvedi R, Sali M, Manganelli R. Mycobacterium tuberculosis virulence: insights and impact on vaccine development. Future Microbiol. 2015;10(7):1177-94.

4. Krishnan N, Robertson BD, Thwaites $\mathrm{G}$. The mechanisms and consequences of the extra-pulmonary dissemination of Mycobacterium tuberculosis. Tuberculosis. 2010;90(6):361-6.

5. Blumberg HM. Burman WJ, Chaisson RE, Daley CL, Etkind SC, Friedman LN, Fujiwara P, Grzemska M, Hopewell PC, Iseman MD, Jasmer RM, Koppaka V, Menzies Rl, O'Brien RJ, Reves RR, Reichman LB, Simone PM, Starke JR, Vernon AA; American Thoracic Society, Centers for Disease Control and Prevention and the infectious diseases society. American Thoracic Society/ Centers for Disease Control and Prevention/Infectious Diseases Society of America: treatment of tuberculosis. Am J Respir Crit Care Med. 2003;167(4): 603-62.

6. Chakraborty S, Rhee KY. Tuberculosis drug development: history and evolution of the mechanism-based paradigm. Cold Spring Harb Perspect Med. 2015;5(8):a021147.

7. Roy A, Eisenhut M, Harris RJ, Rodrigues LC, Sridhar S, Habermann S, Abubakar I. Effect of BCG vaccination against Mycobacterium tuberculosis infection in children: systematic review and meta-analysis. Br Med J. 2014; 349:94643.

8. World Health Organization. Global tuberculosis report 2018. Geneva: World Health Organization; 2018. Licence: CC BY-NC-SA 3.0 IGO. https://apps.who. int/iris/bitstream/handle/10665/274453/9789241565646-eng.pdf Assessed February 14, 2019.

9. Dheda K, Gumbo T, Maartens G, Dooley KE, McNerney R, Murray M, Theron G. The epidemiology, pathogenesis, transmission, diagnosis, and management of multidrug-resistant, extensively drug-resistant, and incurable tuberculosis. The Lancet Resp Med. 2017;5(4):291-360.

10. Gonzalo-Asensio J, Aguilo N, Marinova D, Martin C. Breaking transmission with vaccines: the case of tuberculosis. Microbiol Spectrum. 2017;5(4):1-11. 
11. Achkar JM, Prados-Rosales R. Updates on antibody functions in Mycobacterium tuberculosis infection and their relevance for developing a vaccine against tuberculosis. Current Opinion Immunol. 2018;53:30-7.

12. Laddy DJ, Bonavia A, Hanekom WA, Kaushal D, Williams A, Roederer M, Darrah PA. Toward tuberculosis vaccine development: recommendations for nonhuman primate study design. Infect Immun. 2018;86(2):e00776-17.

13. Kaufmann SH, Weiner J, von Reyn CF. (2017). Novel approaches to tuberculosis vaccine development. Intern J Infect Dis. 2017;56:263-7.

14. Sakai S, Kauffman KD, Sallin MA, Sharpe AH, Young HA, Ganusov W, Barber DL. CD4 T cell-derived IFN-gamma plays a minimal role in control of pulmonary Mycobacterium tuberculosis infection and must be actively repressed by PD-1 to prevent lethal disease. PLoS Pathog. 2016;12:1-22.

15. Cliff JM, Cho JE, Lee JS, Ronacher K, King EC, van Helden P. Excessive cytolytic responses predict tuberculosis relapse after apparently successful treatment. J Infect Dis. 2016:213:485-95.

Ready to submit your research? Choose BMC and benefit from:

- fast, convenient online submission

- thorough peer review by experienced researchers in your field

- rapid publication on acceptance

- support for research data, including large and complex data types

- gold Open Access which fosters wider collaboration and increased citations

- maximum visibility for your research: over $100 \mathrm{M}$ website views per year

At BMC, research is always in progress.

Learn more biomedcentral.com/submissions 